\title{
O povo na democracia como sujeito po- lítico jurídico da Constituição de 88: Centra- lidade dos direitos e garantias fundamentais na relegitimação do poder do Estado no Brasil
}

The people in democracy as a legal political subject of the Constitution of 88: Centrality of fundamental rights and guarantees in the relegitimation of the power of the State in Brazil

Eduardo Almendra Martins ${ }^{1}$ Newton de Menezes Albuquerque 2

Resumo: O presente trabalho tem como objetivo apresentar uma leitura dos poderes estatais como instrumentos legítimos e que desempenham uma

1 Mestre e doutor pela Universidade de Fortaleza, Professor da Faculdade Alencarina de Sobral - FAL e Defensor Público do Estado do Ceará.

E-mail: eduardoalmendra@yahoo.com.br

2 Possui graduação em Direito pela Universidade Federal do Ceará (1993), mestrado em Direito (Direito e Desenvolvimento) pela Universidade Federal do Ceará (1999) e doutorado em Direito pela Universidade Federal de Pernambuco (2001). Atualmente é professor assistente da Universidade de Fortaleza, professor adjunto da Universidade Federal do Ceará, diretor da Fundação Escola Superior Advocacia do Ceará e membro do Conselho Curador da Fundação Perseu Abramo. Atua principalmente em Teoria do Estado Direito Internacional e desenvolve pesquisas com os seguintes temas: sociedade internacional e soberania; Estado nacional e democracia no Brasil e direitos fundamentais.E-mail: newtonma@uol.com.br 
função de concretização dos direitos fundamentais, principalmente na criação de espaços públicos deliberativos do povo. O conceito de povo é analisado para demonstrar que a cidadania não se limita a direitos políticos, mas envolve a atuação dos indivíduos na discussão e influência nos âmbitos de poder. Não há, assim, nenhum poder constituído que escape ao dever de render contas ao cidadão. A linha de pesquisa está voltada para a demonstração de que fora do poder democrático somente há arbítrio, pois sem a participação do povo torna-se inviável a efetivação da justiça no âmbito do Estado. Aqui se fez um estudo bibliográfico, com revisão de literatura, focado em autores que abordam a vinculação entre os direitos humanos e o poder estatal. A Constituição Federal de 1988 é o ponto de encontro entre o ser e dever-ser da relação entre direitos fundamentais e poder estatal, o que impõe uma nova dicção entre legalidade e legitimidade na ação de nossas instituições. O texto normativo de 1988 é âmbito de defesa e promoção de várias vozes para a construção da decisão política.

Palavras-chave: Democracia.Direitos.Fundamentais. Separação.Poder

Abstract: This paper aims to present a reading of the state powers linked to fundamental rights. They are instruments legitimized and of function of concretization of the creation of public spaces deliberative of the town. The concept of people is analyzed to show that citizenship is not limited to political rights, but involves the individuals acting in the discussion and influence in the scopes of power. There is thus no constituted power that escapes the duty of rendering accounts to the citizen. The line of research is focused on demonstrating that outside democratic power there is only arbitrary, and there must be a path of structural 
justice where everyone can participate politically. Here a bibliographical study was carried out, with literature review focused on authors that deal with the link between human rights and state power. The Federal Constitution of 1988 is the meeting point between being and being-must of the relationship between fundamental rights and state power. The normative text of 1988 is scope of defense and promotion of several voices for the construction of the political decision.

Keywords: Democracy.Rights.Fundamental.Separacion.Pariety.Power

\section{Introdução}

A democracia tornou-se um consenso retórico em nossos tempos marcadamente relativistas, quando não, céticos frente à realidade dos valores, o que, por vezes, resultou numa afirmação triunfalista de sua supremacia diante das presunções elitistas que lhe faziam oposição. No campo dos significados, aluda-se a dificuldade na conceituação da democracia, tanto por sua variabilidade histórica de conteúdos, como pela adaptabilidade semântica aberta a diferentes lugares de fala, ou mesmo pela interveniência de toda sorte de epistemologias regionais próprias dos variegados ramos da ciência moderna. Ou seja, como diria uma pensadora de nossos tempos, Simone Goyard-Fabre, chega-se ao ponto, de mencionar que a "a democracia pode ser qualquer coisa." Foi nesse contexto de refundação epistemológica, material da legitimidade do direito, notadamente do constitucionalismo ocidental, revigorada pelos reclamos de restauração da democracia, que se escreveu a Constituição de 88 do Brasil. A crise terminal do ciclo ditatorial militar-empresarial de 1964-1985, solicitava com urgência premente um novo marco 
civilizatório de ordenação jurídico-política e cultural do país. Um documento que expusesse as bases compromissórias de um pacto entre as classes capaz de atenuar os efeitos perversos da concentração de poder, de renda, construídos no período de arbítrio pelas classes dominantes nativas, associadas com os interesses externos, ao tempo que definisse as relações entre os poderes e fluidez aos valores federalistas.

A Constituição de 88, de fato, inovou, não somente ao abrir-se para uma inaudita hermenêutica sistêmica do direito, encimando os direitos fundamentais como sua chave interpretativa central, como ainda amplificou a legitimação ativa de novos atores, pautand o o protagonismo da Sociedade Civil em seus vincos com o ideal de Estado Democrático de Direito. A previsão de mecanismos de participação direta e semidireta da democracia, da autorização de uma dicção mais alargada das ações constitucionais, ou mesmo da responsividade maior das autoridades instituídas, estabelece um patamar de expectativas progressivas na Constituição ora promulgada. Ou seja, ao contrário das Constituições pretéritas, mesmas as mais avançadas como as de 1934 e 1946, a Constituição de 88 propicia um novo engate entre a latência política, democrática do povo enquanto poder constituinte originário, continuamente reconfigurador da realidade institucional e de seus limites; e o poder constituído, positivado, ligado à tutela da segurança jurídica.

\section{A democracia e sua resignificação à luz dos direitos fundamentais na contemporaneida- de}

Hodiernamente, se verifica que as condições radicais da crise de sentido da política e do direito criadas pelo capi- 
talismo e sua atroz competição bélica por mercados no final do século XIX e começo do século XX, culminando com as duas guerras mundiais, exigiam muito mais, do que remendos na ordem vigente ${ }^{3}$. A debaclé europeia somente poderia ser ultrapassada com uma adequada "revisitação" dos fundamentos normativos das estruturas do Estado Capitalista, não somente daqueles compromissados com o fascismo, com o genocídio, a banalidade do desrespeito à vida, mas também, daqueles Estados de Direito liberais ineptos as demandas éticas de cunho humanista. O que requeria uma nova cosmovisão das liberdades em suas respectivas dimensões negativa, positiva e participativa, engendrando assim, uma reinstituição da realidade institucional, suscetível de repor a liberdade em todo seu plexo de horizontes, teórica e prática. Caminhava-se, portanto, das vertentes absenteístas do Estado de Direito - "Guarda-Noturno" - em sua primeira feição, para outro paradigma, o de um Estado calcado na liberdade positiva, este integrador da racionalidade da política, da justiça distributiva, objetivada no Estado Social de Direito, e posteriormente temperado pelas demandas deliberativas, devidamente expressadas no Estado Democrático de Direito.

A assunção do constitucionalismo italiano, alemão, francês, entre outros no final dos anos 40, refundou o pacto

3 Teixeira e Radke concluem que o positivismo como forma de construir regras falhou no intento de normatizar as condutas humanas, deixando, pelo contrário, uma porta aberta para o uso desenfreado do poder, condição propiciatória para o arbítrio. “Naquele momento histórico constatou-se que a teoria jurídica preponderante - o positivismo - havia falhado na sua missão de normatizar e humanizar as condutas, pois serviu de base teórico jurídica para os sistemas responsáveis pela barbárie de duas guerras de enormes proporções em um espaço de tempo extremamente curto. Além disso, assistiu inerte a genocídios e milhares de mortes, a crueldades nunca antes documentadas pela historiografia e a ascensão de regimes antidemocráticos no seio da Europa - i.e., no berço da cultura ocidental e solo mãe da democracia." (2017, p. 83). 
social do poder do Estado, relendo a gramática dos direitos e deveres, mormente, entre outros aspectos, a partir da centralidade dos inúmeros carecimentos da personalidade individual e coletiva do homem, bem como em sua maior dialogicidade com as normas internacionais, tangenciando um direito mais dúctil, impreciso, argumentado, mas também próximo dos fatores materiais da normalidade social. Constitucionalismos que se ligam a razão sensível da cidadania, advinda dos movimentos sociais, das inúmeras diferenças que definem cada pessoa, refazendo os termos do pluralismo, para além de sua perspectiva individualista.

Tal tendência de superação da crise espiritual europeia permitiu uma revisão dos conceitos de legitimidade, distanciando-se do veio meramente procedimentalista que a engessou. Precisava-se resgatar o comum, o sentido axiológico da vida humana, por meio de uma redescoberta da ética laica, de seus nexos de intersubjetividade entre as pessoas. Mesmo porque tanto a democracia, quanto o direito, dimana dos valores precípuos da dignidade humana, do reconhecimento recíproco, da alteridade que nos complementa, sem os quais, a ideia de direitos fundamentais adquire uma funcionalidade decorativa. Daí, o surgimento do neopositivismo, das diferentes teorias constitucionalistas que reposicionaram a democracia, bem como o direito, em relação à uma moral objetiva, ética, porosa a política e ao sentido originário, clássico, de abertura ao bem-comum. Neopositivismo que reposicionou o direito em relação aos reptos da moral jusnaturalista, sem recair na tentação de suas posturas excessivamente metafísicas.

Contudo, hoje, há um crescimento de formas autocráticas renovadas de compreensão da política e do direito no Brasil e no mundo, ao tempo que se mantém, e em alguns casos se dilata, a presença retórica, documental, dos direitos 
humanos no bojo da argumentação político-jurídica, ainda que acompanhado, paradoxalmente, de seu gradual esvaziamento como espaço normativo específico, dada a valência maior das motivações do Estado de Exceção Pró-Mercado sobre o estatuto da cidadania.

A presumida autoreferencialidade do direito moderno, nunca efetivado em nosso Estado periférico, mais uma vez é toldada por fatores heterônomos, conjugado a uma ausência de uma cultura legalista ou constitucionalista no país. A regurgitação de práticas e concepções conservadoras, de nítido teor hierático, visa sobrepor à Constituição, os fatores reais de poder. Para piorar, não se olvida a intensificação do paradigma da "sociedade do espetáculo" em que a publicidade tolda as relações interindividuais autênticas, constrangendo-as em suas autonomias morais. A influência da mídia corporativa, do dinheiro sobre as eleições, talvez, seja o caso mais emblemático das distorções sofridas pelos mecanismos representativos, ao conspurcar a esfera pública, impedindo o livre e equilibrado debate sobre as alternativas políticas disponíveis.

No caso do Brasil, a realidade parece mais grave, haja vista que nem sequer foram edificadas as bases de uma modernidade capitalista liberal, a julgar pela dualidade das estruturas políticas e jurídicas,vez que há uma abissal distinção de acesso ao capital social entre as pessoas, assim como a renda básica para prover-se garantias e direitos para todos, dificultando o exercício universal dos destes. A própria Constituição de 88, a Carta dos Direitos Fundamentais, ideário de uma inédita pactuação entorno da incorporação de todos brasileiros aos direitos e deveres, encontra-se em crise. Basta examinar a atuação insatisfatória do STF como Corte Constitucional, incapaz de fazer valer a força normativa, vinculativa da Constituição de 88. Apesar disto, e até 
por isso mesmo, acredita-se que a luta pela efetivação da Constituição de 88 e de seus fundamentos civilizatórios, calcados nos direitos fundamentais, cobram ações enérgicas voltadas para revigorá-las, reformá-las e revolucioná-las, aprofundando a eficácia de seus comandos teleológicos.

A fórmula canônica do Estado Democrático de Direito, oriundo da síntese contraditória dos valores da positividade, previsibilidade e segurança do direito, da pulsão instituinte e pluralista da democracia, e da afirmação das autonomias individuais e social, somente adquire concretude, na medida em que se é capaz de incorporar um sentimento constitucional junto às maiorias, para que estas ajam como sujeitos controladores e reinstituintes do poder. Afinal nem o Estado de Direito, nem a democracia são "naturais" no Brasil, mas conquistas árduas, obtidas ao contrapelo das classes dominantes, estas caudatárias de cosmovisões elitistas, anti-humanistas e dependistas. Nesse diapasão, cabe às forças populares com fulcro em sua auto-organização, vontade ético-política, resgatar o avatar da democracia e seus nexos inextrincáveis com os direitos fundamentais, ambos colados a primazia fundante da dignidade da pessoa humana sobre toda e qualquer razão de Estado.

\section{Democracia: o povo como novo absoluto do poder do Estado}

A democracia não é um conceito à sombra do tempo e do espaço, mas expressão contraditória de processos políticos, culturais, econômicos dimanados de interesses diversos, por vezes antagônicos. Já foi grega, francesa, americana, alemã, latino-americana, flertou com doutrinas organicistas, mecânicas, mas sempre se pautou pela preocupação com a afirmação de um poder compartilhado, conformado pela 
dialética entre os muitos e a unidade sintética do poder, seja este em sua forma-comunidade, ou sua forma moderna de Estado.

Nesse contexto, portanto, se verifica que a formação e o substrato do conceito democrático são ideais e históricos, ou seja, é estático e dinâmico, sendo mediado pela práxis dos sujeitos que a fazem e refazem continuamente. Por conseguinte, a democracia não é nem um ideal, nem somente representação do real, mas uma amálgama de ambas as faces, uma construção própria de uma cultura política, logo a "democracia resulta de interações entre seus ideais e sua realidade é moldada por elas: pelo impulso de um dever ser e pela resistência de um $e^{4} . "$

Na evolução das ideias jurídico-políticas, destacaríamos a fundamentação antropológica do poder na modernidade, notadamente com o advento da visão liberal-burguesa do Estado assentado na presumida autonomia de vontade dos indivíduos. O Estado e sua "persona" ficcional vinculam-se a uma ordem temporal, espacial, de valência absoluta, mas dotada de ares de racionalidade mundana ${ }^{5}:$ "[...] o princípio de independência da soberania se deixa subsumir, [...], pelas categorias da razão humana. [...] não é filosoficamente necessário inserir a soberania numa doutrina teocrática ${ }^{6} . " \mathrm{O}$ racionalismo humano se exterioriza, portanto, com a ideia

4 SARTORI, 1994, p. 24.

5 GOYARD-FABRE, 2002, p. 171

6 GOYARD-FABRE, 2002, p. 151. GOYARD-FABRE sintetiza a mudança do "absoluto" soberano da seguinte forma. "Já não é o rei que, sem oposição, é reconhecido como titular eminente da soberania; essa concepção assumiu uma feição obsoleta e é tão caduca que só poderia ter aplicação num regime 'antigo', definitivamente ultrapassado pelo acontecimento revolucionário. De fato, só o corpo público - seja ela chamado de povo ou de nação - é declarado detentor da soberania e, mesmo através de seus representantes, ele não deve, e alias não poderia sem negar a si próprio, alienar-se (2002, p. 185). 
dos homens unirem-se através de um contrato hipotético e assim construir um ente político que atenda a necessidade daqueles exercerem suas liberdades sem o constrangimento de vê-la esvaziar-se: "o homem é artifex, ser capaz de não somente reproduzir, imitar a natureza, mas também de aperfeiçoá-la, melhorá-la, dar-lhe um fim mais nobre, e capacitá-la a servir aos fins humanos ${ }^{7 \prime}$.

Para Rousseau a dificuldade da existência prática de uma democracia está na manutenção do povo em contínua assembleia, deliberando sobre tudo, daí a razão para ele afirmar que "[...], nunca existiu verdadeira democracia nem nunca existirá8." Rousseau vê no povo a fonte do poder soberano, imperativo, não podendo seus representantes contrariar os anseios da" vontade geral", pois apesar do poder ser transmissível, a vontade que constitui a soberania, o máximo poder, não o é 9 .

Não se olvide, segundo Heller, que a ideia abstrata de "vontade geral" impõe uma limitação da compreensão sobre o povo "concreto", formado de indivíduos regidos por interesses mundanos, o que pode propicia um uso manipulatório do conceito, quase sempre favorável aos detentores do poder. O povo, segundo, aquele, é uma estrutura histórica que se pereniza no tempo, apesar das várias mudanças, mas que demanda a mediação de processos institucionais para vir a ser operado. Ademais, a unidade do povo decorre da manutenção de seu caráter simbólico que são assimilados e repassados por gerações, preservando sua peculiaridade agregativa cultural ${ }^{10}$. Logo, a "vontade geral" no ideal rousse-

\footnotetext{
7 BITTAR, 2002, p. 150.

8 ROUSSEAU, 2011, p. 122

9 ROUSSEAU, 2011, p. 77

10 HELLER, 1968, p.198.
} 
auniano romantiza, abstratiza o povo, em oposição ao povo real, que para Heller é uma comunidade em oposição ${ }^{11}$.

A "vontade geral" é construída, portanto, pelos desacordos contidos no povo real, nos conflitos inerentes aos choques de classes sociais que marcam a formação e o funcionamento das sociedades modernas. Nesse contexto, Dahl demonstra que tanto a racionalidade abstrata, como os sentimentos coletivos são formadores do procedimento democrático, logo, quando a razão ${ }^{12}$ serve como um guia para a justiça, os sentimentos, "[...] que van desde la compasión hasta la envidia, la ira y el ódio ${ }^{13 "}$ ", em oposição, impelem as ações políticas. Mesmo porque a razão move-se em intima relação com o sentimento, esse deflagrado por nossa situação frente ao mundo e aos outros, não obstante o refreio dos elementos pulsionais mais latentes, na laboração reflexiva, ideológica. A irresignação pela condição de vida também é vista por Marx e Engels como elemento constitutivo das reivindicações de uma sociedade mais justa e igualitária - denominada por eles de comunismo -, onde os indivíduos autônomos agregados pelo trabalho comum seriam o fautor da produção e exercício do poder, ou seja, as relações de tensão entre oprimidos e opressores, sempre foram o humos para uma transformação da sociedade. ${ }^{14}$.

Nessa quadra, Texier ${ }^{15}$ afirma que Marx e Engels não identificam qual seria o regime de governo do comunismo ${ }^{16}$,

11 HELLER, 1968, p.198 e 201.

12 Aqui não se olvida que as razões contribuem para construção de um caminho para a justiça, e o termo razões contem as faces: subjetiva, objetiva e intersubjetiva.

13 DAHL, 2008, p. 44.

14 MARX, ENGELS, 2011, p. 40.

15 TEXIER, 2005, p.192.

16 Afinal a referência à ditadura do proletariado não exclui a democracia, mas, apenas, a compreende sob o signo da parcialidade ínsita a condição 
mas que deveria ser compreendido como um desenvolvimento potenciado da democracia, aprimorando como nunca o sentido da autonomia individual e social do homem. Um ideal prático comunista, fundado na igualdade e liberdade formal e material, capaz de consubstanciar práticas cooperativas, dissensos e dimensões auto-organizativas das comunidades pós-estatais, logo, “[...] a sociedade não pode ter outro fim que não seja a busca da felicidade individual dos seus membros e a permanência, equilíbrio e evolução dela própria ${ }^{1{ }^{\prime \prime}}$. Daí a crítica ao capitalismo por atribuir o primado à lei abstrata do valor, do dinheiro em detrimento do homem concreto, alienando-o dos processos materiais cooperativos do trabalho e da política. A democracia é condição e é fim para o auto-reconhecimento do homem por meio do comum, da busca da felicidade terrena ${ }^{18}$.

A soberania na modernidade burguesa ao identificar-se com o rei, depois com o Estado, afastou-se do sentido instituinte, aberto, vinculado ao jogo contraditório de interesses que conforma o povo em sua feição existencial, assumindo uma feição dogmática, fechada, homogênea, identificado com a nação, enquanto o povo proletário forceja por produzir a democracia pautada "[...] no pluralismo de modos de vida de sistemas de credos e convicções ${ }^{19^{\prime \prime}}$. Retirar o manto metafísico de tais postulados, situando-os ao rés do chão das ações instituintes dos que fazem e refazem o mundo, cooperando, numa ética diária de trocas não-instrumentais, mas comunicacionais, políticas, jurígenas, é o caminho para repensar a democracia em nossos tempos de crescente complexidade e heterogeneidade. Um caminho coordenado pela

particularista da existência das classes sociais e de seu antagonismo.

17 BRITTO, 2010, p. 21.

18 BRITTO, 2010, p. 20.

19 TEIXEIRA;RADKE, 2017, p. 90 
linguagem, onde as pessoas buscam construir um ambiente social válido, ou seja, “[...] os atores, na qualidade de falantes e ouvintes, tentam negociar interpretações comuns da situação e harmonizar entre si os seus respectivos planos através de processos de entendimento, portanto, pelo caminho de uma busca incondicionada de fins ilocucionários ${ }^{20}$."

Nação, Estado, Povo, precisam ser re-problematizados, superando o significado substitutivo-hierático de suas leituras modernas, mais preocupadas com a legitimação contramajoritária dos interesses do homem-proprietário-burguês, do que com a fluência multitudinária do pluralismo autêntico dos indivíduos comuns e suas vocações associativas. Enfim, precisa-se de uma democracia verdadeiramente democrática, de um Estado, sem Estado, de um poder sem poder, pois autofundado na própria potência dos homens reunidos por suas vontades, livres da subordinação da propriedade, do dinheiro e do mercado.

\subsection{Como identificar o Povo pluralista?}

Após essa conquista do povo como titular da soberania, surgem outros problemas, como a identificação do "povo", isto é, quais são as pessoas que integram essa noção, que elementos jurídico-políticos podem caracterizar o povo? Essa pergunta não deve ser respondida apenas no nível da atividade de participação eleitoral, pois o exercício do sufrágio por mais que tenha se alargado, ao ponto da Constituição de 88 afirmar no art. 14, cabeça, que ele é universal, ainda há restrições para seu exercício, na medida em que algumas pessoas são impedidas de votar, como os estrangeiros ${ }^{21}$, os

20 HABERMAS, 2012, p. 36

21 A lei 13.445 de 24 de maio de 2017 que trata sobre a migração no Brasil deixou de contemplar o voto do estrangeiro, permitindo apenas no art. 71 que o 
conscritos (art.14 $\S 2^{\circ}$ ) e aqueles que tenham seus direitos políticos suspensos (art. 15, cabeça). Seriam esses tolhidos do resguardo de suas dignidades dentro da República Federativa do Brasil? Logo se percebe que não, pois a Constituição alarga os direitos fundamentais para todos os que estejam no território brasileiro, portanto: "quanto mais o 'povo' for idêntico com a população no direito efetivamente realizado de uma sociedade constituída, tanto mais valor de realidade e consequentemente legitimidade terá o sistema democrático existente como forma ${ }^{22}$ ". Essa condição é necessária para comportar o dissenso que permeia a realidade social, pois como o povo não é um bloco monolítico ${ }^{23}$, mas um amálgama que busca por meio da Constituição disciplinar suas tensões ${ }^{24}$, cada pessoa deve compreender "[...] o fato de que a nossa consciência não é a única as voltas com os tópicos da justiça e de que devemos compartilhar o mundo com outros que podem discordar de nós $[\ldots]^{25}$."

naturalizado, após 01 não de sua concessão, compareça à Justiça Eleitoral para se cadastrar. Não se entende a razão dessa limitação de uma não, nem mesmo porque não se avançou na concessão do direito ao voto para o estrangeiro que aqui reside. Importa destacar aqui o desenho institucional proposto por Linares tendo como base argumentativa que a igualdade política deve está aparejada com a interferência no aparelho coercitivo estatal sobre o qual se vive. "El ideal democrático que defiendo sostiene el principio de que todos los que están sujetos de manera permanente a la coerción del Estado tienen el derecho a participar en la toma de decisiones políticas en pie de igualdad.(2017, p. 320) (...). Con arraigo en estas ideas he defendido un sistema que otorga de manera incondicionada derecho de voto a todos los residentes permanentes, y solo de manera condicionada - y por razones estratégicas de recirocidad interestatal - derechos de voto a los ciudadanos que residen en otro país, siempre que se cumplan dos condiciones: si el Estado en el que residen no reconoce derecho de voto a los residentes extranjeros, y/o si el estado en el que residen reconoce derecho de voto a sus ciudadanos residentes en el exterior." (2017,p. 335 e 336).

22 MÜLLER, 2011, p. 95

23 HELLER, 1986, p. 200.

24 FERRAJOLI, 2012, p. 81.

25 WALDRON, 2003, p. 95 
O Estado, portanto, para ser considerado democrático, não pode fiar-se apenas ao regime que inaugura, não pode se limitar a "[...] uma mera eleição de representantes que decidem em nome do povo $[\ldots]^{26^{\prime \prime}}$, pelo contrário, deve propiciar um ambiente institucional e não institucional, onde a deliberação, a comunicação estabelecida proporcione " [...] um processo constante de participação dos cidadãos na atividade estatal $[\ldots]^{27 \prime}$. Assim sendo, um regime normativamente democrático ao criar instituições públicas abertas à participação e controle do povo estrutura um desenho institucional que viabiliza e consolida a democracia ${ }^{28}$.

Daí porque, a democracia ao afirma-se como tal, deve reconhecer a potência instituinte da política, ainda que fruindo da relevância do direito como positivação das liberdades, como generalização congruente de expectativas como aludia Luhmann. Já que a democracia na contemporaneidade só pode viabilizar-se partindo da inevitável condição do pluralismo complexo que modela a sociabilidade. Por isso, a necessidade da constante convivência com opostos, gerando movimentos de tensões, que em vez de ameaçar, complementa em sua indispensável alteridade. Daí porque se pode afirmar que a Assembleia Constituinte que intenta refundar a sociedade-estado é um microcosmo onde cada um de seus membros traz "para a decisão coletiva uma série díspar de visões, perspectivas, discernimentos e experiências ${ }^{201}$, a fim de construir a fundamentalidade constitucional.

O povo dentro da República Federativa do Brasil é, portanto, constituído por todas as pessoas que se submetem ao ordenamento jurídico constitucional brasileiro, sejam elas,

26 FURTADO, 1993, p. 113

27 FURTADO, 1993, p. 113

28 ALVES, 2004, p. 20.

29 WALDRON, 2003, p. 120 
eminentemente individuais, sejam em suas figurações coletivas, decorrentes dos metabolismos participativos. Logo a cooperação como elo entre o eu e o outro, para a construção da democracia é elemento intrínseco de sua autoconstrução, como de sua validação legitimadora posterior, sendo, portanto, inalienável e intransmissível, pois se trata de sua propriedade política originária ${ }^{30}$. E a participação popular viabiliza-se de forma processual, descontínua e por vezes com certa dose de imprecisão, pois essa ainda está em plena construção intuitiva, sujeita a interferências ameaçadoras de outras esferas. A necessidade dos ajustes, bem como do calibramento do tempo, da potência da política em sua expressão democrática com a contingência do momento, da contrafactualidade do direito, é um desafio perene. A Constituição de 88 como desdobramento de um momento de quebra da ordem autocrática e de emergência de um novo paradigma de inclusão universal de direitos fundamentais, oriundo da vontade instituinte do povo concreto em meio a suas tensões, contradições e pulsões, embute questionamentos frequentes sobre a persistência de seus comandos, face aos choques fáticos de uma sociedade tão desigual e injusta.

A tibieza de nossos ciclos democráticos, a intangibilidade dos núcleos duros de poder aos ditames da cidadania regulada pelo direito confirma tal lamentável prognóstico, porém, cabe sempre a defesa constante da democracia e das boas razões do constitucionalismo, preservando as balizas traçadas pela Constituição de 1988, "numa espécie de viagem civilizatória sem volta ${ }^{31}$." Avançar na veia instituinte de direitos, prerrogativas, garantias, sim; retroceder, conciliar com as cadeias do neo-escravismo, mascarado pela apologia a liberdade dos mercados selvagens, jamais. A Constituição

30 WALDRON, 2003, p. 139

31 BRITTO, 2010, p. 20 
precisa ser normativa, transformar-se em vida concreta, vivida, espantando os fantasmas das Constituições semânticas ou nominais, que em regra, pautaram a existência do povo enquanto tal.

\subsection{O povo instituinte e a vinculação dos poderes constitucionais aos direitos e garantias funda- mentais}

A Constituição de 1988 para romper, então, com um passado de autoritarismo e solipsismo ${ }^{32}$ impõe como fim do Estado que o poder seja exercido para a construção de uma sociedade justa, igualitária que possibilitasse o desenvolvimento de todos os integrantes de uma sociedade pluralista, objetivos contidos, por exemplo, nos incisos do art. $3^{\circ}$ da $\mathrm{CF} / 88$. A democracia, assim, não se satisfaz apenas com uma forma de ser, exige também uma substância mínima que permita a discussão pública igual. Nessa conjuntura se fala em uma democracia de dois vértices ${ }^{33}$. A democracia, portanto, não se resume a jogos de procedimento democrático, como a representação de uma maioria, ou mesmo a garantia de sufrágio universal, mas sim a proteção irrestrita dos direitos

32 "Do latim solus (sozinho) e Ipse (mesmo), o solipsismo pode ser entendido como a concepção filosófica de que o mundo e o conhecimento estão submetidos à consciência do sujeito. Ele sujeita o mundo conforme o seu ponto de vista interior. Epistemologicamente, o solipsismo representa o coroamento da radicalidade do individualismo moderno em seu sentido mais profundo. [...]. Com efeito, na teoria da decisão devemos, fundamentalmente, evitar que esta seja dado por ideologia, subjetividade ou interesses pessoais, porque esse é o espaço em que entre o sujeito solipsista mais especificamente."(STRECK, 2017, p. 273 e 276).

33 Britto (2010, p. 33-34) fala na existência de uma democracia de três vértices, acrescentando as duas já citadas a democracia fraternal, em que se trataria da defesa do meio ambiente e da necessidade de respeito ao pluralismo. 
e garantias fundamentais ${ }^{34}$, daí se falar em democracia substancial. Nesse ponto vista, Dahl elenca várias características de uma democracia ideal. Ele inicia fazendo menção às regras do procedimento político para ao final afirmar a necessidade de uma ordem jurídica baseada em direitos fundamentais, para ele "[La] democracia consiste entonces, no sólo em processos políticos. También es, necessariamente, un sistema de derechos fundamentales ${ }^{35}$. Esses direitos fundamentais devem atuar como precondições para a deliberação, com isso se quer afirmar que as pessoas devem ter condições de igual consideração e respeito em suas liberdades para expressarem seus dissensos. A corrosão democrática com a Constituição posta como uma folha de papel ocorre quando, além de outros fatores, "[...] son frustradas por el fracaso de dar a la gente iguales medios para participar efectivamente en el proceso de deliberación y en la toma de decisión mayoritaria. ${ }^{36}$

Os direitos fundamentais foram, desse modo, escolhas feitas pelo Poder Constituinte dentro de uma variedade de princípios jurídicos, positivando os que melhor venham a expressar a valorização humana dentro da histórica cultural de uma sociedade ${ }^{37}$. Já as garantias fundamentais seriam, em

34 Não se pode deixar de realizar a distinção entre direitos e garantias, já que são realidades normativas que significam coisas diferentes, mas que não se excluem, antes são organizadas como elementos de integração. Nesse contexto uma realimenta a outra para que ambas sejam exequíveis e expandam a proteção sobre o humano, levando em consideração, portanto, a advertência de Ferrajoli:" [...] si confundimos derechos y garantias resultarán descalificadas en el plano jurídico las dós más importantes conquistas del constitucionalismo de este siglo, es decir, la internacionalización dos derechos fundamentales y la constitucionalización de los derechos socialis, reducidas uma y outra, em defecto de las adecuadas garantías, a simples declamaciones retóricas, o al lo sumo, a vagos programas políticos jurídicamente irrelevantes." (2010, p. 59).

35 DAHL, 2008, p. 24

36 NINO, 2003, p. 193

37 LOPES, 2010, p. 35 
nível primário, as proibições e obrigações de respeito aos direitos fundamentais, e em nível secundário, surgiriam apenas para que o Estado aplicasse aquelas sanções, decorrentes do reconhecimento de nulidade da violação dos direitos ${ }^{38}$. Observa-se aqui o caráter instrumental das garantias de modo a viabilizar a proteção dos direitos a que se referem.

A parametricidade desempenhada pelos direitos fundamentais positivados no sistema constitucional brasileiro não se resume à existência dos direitos políticos, ou seja, de sufrágio, mas se estende sobre as condições do sujeito que os exerce, ou seja, a democracia deliberativa preocupa-se com o contexto social em que está inserido o indivíduo que vai as urnas para eleger seus representantes, pois "[Se] os cidadãos não têm sua autonomia privada respeitada, não têm por que cooperar ${ }^{39^{\prime \prime}}$, quer dizer, participem do processo democrático de modo livre sem ter que barganhar seu voto por um prato de comida, moradia, educação ou atendimento médico. A democracia substancial ${ }^{40}$ tem como ponto de partida, portanto, os fundamentos da República Federativa do Brasil, art. $1^{\circ}$ e seus incisos, perpassando por toda a previsão explícita e implícita de direitos fundamentais decorrentes daquele regime e dos princípios por ela adotado, ou dos tratados internacionais celebrados ${ }^{41}$, cujo conteúdo

38 FERRAJOLI, 2010, p. 59

39 SOUZA NETO, 2006, p. 57

$40 \mathrm{Se}$, de fato, as normas formais sobre o vigor se identificam, no Estado democrático de direito, com as regras da democracia formal ou política, enquanto disciplinam as formas das decisões que asseguram a expressão da vontade da maioria, normas substanciais sobre a validade, vinculando à pena de invalidade a substância (ou o significado) das mesmas decisões em respeito aos direitos fundamentais e aos outros princípios axiológicos neles estabelecidos, correspondem às regras com as quais bem podemos caracterizar a democracia substancial. (FERRAJOLI, 2011, p. 27)

41 Aqui se insere não só os direitos fundamentais explícitos do art. $5^{\circ}$ 
verse sobre direitos humanos, buscando atingir os objetivos do art. $3^{\circ}$, da CF/88. Nesse caminhar dos fundamentos aos objetivos da Constituição de 1988 se revela o conteúdo do Estado Democrático de Direito. Salutar a consideração de Ferrajoli de que a defesa dos direitos fundamentais é uma construção de muros de pedra em torno do contrato social que ergue o Estado:

Sob esse aspecto, podemos bem dizer que o paradigma da democracia constitucional é filho da filosofia contratualista. Num duplo sentido. No sentido de que as constituições outra coisa não são que contratos sociais em forma escrita e positiva: pactos de fundantes da convivência civil gerados historicamente pelos movimentos revolucionários que foram impostos aos poderes públicos, de outra forma absolutos, como fontes da sua legitimidade. E no sentido de que a ideia do contrato social é uma metáfora da democracia: da democracia política, dado que alude ao consenso dos contraentes e vale então fundar, pela primeira vez na história, uma legitimação de baixo, e não do alto, do poder político; mas também uma metáfora da democracia substancial, dado que esse contrato não é um acordo novo, mas tem como cláusulas, e conjuntamente como causa e razão precisas, a tutela dos direitos fundamentais, cuja violação por parte do soberano legitima a ruptura do pacto e o exercício do direito de resistência ${ }^{42}$.

Para a conjugação da democracia formal ou procedimental com a substancial há a necessidade de se entronizar os direitos fundamentais, colocando-os como "vínculos sustanciales normativamente impuestos - en garantia de instereses y necessidades de todos estipulados como vitales, por eso fundamentales (la vida, la libertad, la susbistencia) - tanto a las decisones de mayoria como al libre mercado ${ }^{43}$ ", pois a decisão desses não

da $\mathrm{CF} / 88$, mas também todos os direitos inseridos dentro do bloco de constitucionalidade referido pelo $\S 2^{\circ}$ do mesmo artigo.

42 FERRAJOLI, 2011, p. 28-29

43 FERRAJOLI, 2010, p. 51 
torna algo certo simplesmente por pensarem ser certo, pelo contrário, "[É] justamente esse o problema: não torna ${ }^{44}$.".

A proteção dos direitos fundamentais é necessária para a construção de um regime democrático forte, pois a existência digna remete a uma consideração de valores que foram construídos e considerados de suma importância, tendo a liberdade e igualdade como binômios de saída e chegada. Nessa medida todos os direitos contemplados em um texto constitucional são para a criação de situações propiciatórias para o melhor desenvolvimento daqueles valores. Não se olvidando, que a prescrição daqueles direitos é apenas um início de força para a proteção do ser humano, pois a inexistência de instituições que tornem efetivos os direitos é o mesmo que construir castelo de areia, ou melhor, "o humanismo dos dias atuais ainda é mais de fachada do que autêntico ${ }^{45}$.", logo não se dar alicerce à obra dos direitos fundamentais é retirar-lhes a força contra as águas do absolutismo.

\subsubsection{A maquina legislativa operando com e pelos direitos fundamentais}

Nesse contexto, a democracia formal, ou procedimental, e a substancial, ou material, dialogam e não se excluem, conformam um eixo complementar aberto a novas realidades experimentais oriundas da vida, do trabalho, daí não se concordar totalmente com Jorge Neto $^{46}$ quando critica ferozmente a imagem política atual, ao considerá-la cooptada por grupos superiores em organização e economicamente influentes ${ }^{47}$.

44 WALDRON, 2003, p. 97

45 BRITTO, 2010, p. 45

46 JORGE NETO, 2008, p. 86.

47 Cyrino (2016, p. 61) explica essa situação quando afirma que dentro de uma 
Nesse sentido, não se pode negar que na evolução do sufrágio na história da humanidade, após a revolução francesa, a burguesia impôs vários limites à participação dos representantes das massas no Parlamento, quer através da instituição de critérios econômicos e de raça, quer de fórmulas eleitorais de dois filtros em que os votos dos vulneráveis eram desprezados e aglutinados aos dos ricos, além da restrição de gênero que se fazia ao voto. Essa discriminação foi observada por Losurdo: “[E], portanto, ainda que conjugado no futuro, o sufrágio universal não deve, de qualquer modo, ser igual para todos: aos melhores e mais inteligentes deve ser assegurada, já pela via legislativa, uma influência superior na vida pública ${ }^{48}$. A despeito de sua validade para o Brasil, dada sua história repleta de interdições de natureza capacitaria que veem o povo como "incapaz de discernimento político, como apático, incompetente, corrompível, enganável, que vimos nos debates sobre eleição direta, revelando visão míope, má-fé, ou incapacidade de percepção $0^{49^{\prime \prime}}$. Não se pode, pois, descartar a democracia representativa como algo superado, mormente a popular, como apregoavam desde a monarquia, pois "[Nosso] respeito pela legislação é, em parte, o tributo que devemos pagar à conquista da ação concertada, cooperativa, coordenada

perspectiva realista os representantes agem como homo economicus, buscando a maximização de seus interesses. "Neste caso, interesses orientados por uma necessidade básica: manter-se no poder, de preferência incrementando-o. Para isso, numa democracia representativa, o político precisará de votos suficientes para ganhar uma eleição, o que demanda uma campanha que, por seu turno, requererá dinheiro e apoio político. Assim, os agentes públicos eleitos tenderão a agir com esse foco, como ocorre, por exemplo, com a possibilidade de utilização do orçamento para projetos políticos individuais e a obtenção de mais votos."

48 LOSURDO, 2004, p. 35

49 CARVALHO, 2011, p. 67 


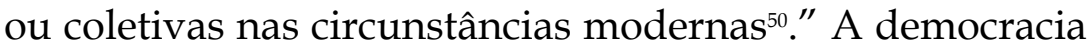
indireta é necessária numa sociedade complexa, pluralista e de vasto território, em que as mediações dos interesses variados do povo possa viabilizar-se, sem expurgos ou silenciamentos. Esse importante âmbito de discussão política sobre os interesses da comunidade, que é o parlamento, não pode perder de vista a necessidade de se manter "[...] uma instituição diversa e plural e que por meio de algo como a responsabilidade eleitoral, incorpore o espírito do autogoverno $[\ldots]^{51}$ ", salientando-se que a "[...] deliberação que confronte as nossas diferenças em público e estabeleça uma opinião comum como uma questão de escolha social [... $]^{52 "}$ deve observar as escolhas feitas pelo legislador constituinte ao buscar a solução final das discordâncias sobre a justiça social que o Estado brasileiro busca.

A representação política para existir, então, exige procedimentos que a torne a mais legítima possível, como, o plebiscito, referendo e iniciativa popular de projeto de lei, como se extraí do art. 14, incisos I, II e III da CF/88. Esse momento de soberania popular em sua face direta, no sentido da titularidade do povo no controle do poder, favorece a democracia representativa, repolitizando-a.

Contudo, mesmo com a possibilidade de atuação direta do povo na gestão democrática do poder de criação das leis, como posto na Constituição de 88 e na Lei 9.709 , de 18 de novembro de 1998, que segundo seu preâmbulo: "regulamenta a execução do disposto nos incisos I, II e III do art. 14 da Constituição Federal", o que se observa ao fim é que o exercício da democracia direta fica unicamente nas mãos do Poder Legislativo e Executivo. Na medida em que segundo

50 WALDRON, 2003, p. 190

51 WALDRON, 2003, p. 106

52 WALDRON, 2003, p. 109 
os art's. $3^{\circ}, 5^{\circ}, 6^{\circ}$ e 13, caberão àqueles órgãos a convocação para o plebiscito e referendo, e no caso da iniciativa popular de lei poder-se-á rejeitar o projeto ou mesmo introduzir alterações significativas ao ponto de modificar seus escopos. Nesse sentido, Müller:

No primeiro caso, é a elite política que tem a competência de formulara questão e de enquadrar, de limitar deste modo, a extensão do que deve ser decidido e, depois, é o povo que deve decidir pelo conteúdo - mas somente em um quadro pré-decidido; e a iniciativa, de todo modo, está sempre inteiramente à disposição dos políticos. No segundo caso, é o povo que tem a iniciativa e também a competência de decidir o conteúdo da proposição - mas a decisão definitiva está complemente nas mãos da elite política. Tudo isso demonstra que estas três formas de legislação popular não são, na realidade, autônomas, que elas não pertencem à competência essencial do povo, que elas não formam nenhum contrapeso eficaz à legislação representativa-parlamentar ${ }^{53}$.

Mesmo diante da crítica de Müller, o povo nesses mecanismos acaba por expressar sua vontade, que deve ser levada em consideração pelos seus representantes eleitos, já que "[O] desenvolvimento constitucional no último século, portanto, fortaleceu substancialmente o compromisso original com o controle do governo pela maioria dos governados ${ }^{54}$, exigindo um ambiente político aberto a fim de que suas reivindicações e críticas tenham igual consideração e respeito mesmo diante de interesses do capital econômico. Logo, a salvaguarda de interesses privados pelos parlamentares como pontuado pela crítica, acima, acaba por desconsiderar os meios de acesso direto à informação existente, isto é, instrumentos que possibilitam a discussão pública e em pé de igualdade, pois não há restrição às críticas veiculadas nos espaços direcionados como audiências públicas,

53 MÜLLER, 2011, p.68

54 ELY, 2010, p. 11 
passeatas, bem como nos não direcionados, como as redes sociais. Portanto, se verifica que a deliberação no espaço não institucional - "[...] aquella que se desarolla amplia, difusa e informalmente en múltiples espacios y contextos de la esfara pública que no están juridicamente estabelecidos y no desencadenan una decisión jurídica ${ }^{55}$ " - acaba por racionalizar e legitimar o processo decisório, já que a decisão necessita ser construída em direção a salvaguarda de direitos fundamentais ${ }^{56}$.

Observa-se, portanto, que a representação legislativa passa por uma releitura de legitimidade, na medida em que a sociedade não vê o legislador como única instância de decisão política que constrói o direito, já que se pôs de lado o fetichismo legal, ou seja, a infalibilidade da lei, na medida em que o "o legislador é apenas outro ser humano - ou grupo de seres humanos - tentando compreender as coisas ${ }^{57 "}$ cujo raciocino está sujeito aos mesmos vícios que outro membro da comunidade poderia ter ${ }^{58}$ ao ponderar os bens a serem distribuídos dentro de um planejamento para o Estado ${ }^{59}$.

Igualmente, não se pode esquecer que o Parlamento é utilizado por uma maioria episódica, ou mesmo uma minoria elitista que possa tornar-se maioria ${ }^{60}$, daí porque assistir razão a Ely quando afirma que "[...] a tarefa mais difícil sempre foi e continua sendo a de criar uma ou mais maneiras de proteger as minorias da tirania da maioria $[\ldots]^{61^{\prime \prime}}$, pois as

55 MARTÍ, 2006, p. 80

56 SOUZA NETO, 2006, p. 59

57 WALDRON, 2003, p. 73

58 WALDRON, 2003, p. 74

59 TORRES, 2009, p. 169

60 Sublinhe-se a crítica feita acima, na página 34, por Dante de Oliveira, quando da rejeição da emenda que instituía as eleições diretas a Presidência da República antes da nova ordem constitucional de 1988.

61 ELY, 2010, p. 12 
maiorias só se legitimam na medida em que buscam a igualdade material de participação política, ou seja, " [El] gobierno de mayoría está justificado sólo como un medido para alcanzar la igualdad política ${ }^{62^{\prime \prime}}$. As cláusulas pétreas do $\S 4^{\circ}$, do art. 60 da CF/88 funcionam como instrumento de vinculação direta sobre o Poder Legislativo, na medida em que impedem que esse através de deliberações majoritárias revogue direitos fundamentais inscritos na Constituição. Portanto, é possível a regulamentação dos direitos fundamentais, todavia, essa não pode ter o intuito de esvaziar o conteúdo do direito fundamental regulamentado, do contrário, permitir-se-ia uma abolição implícita dos preceitos constitucionais protegidos pela cláusula de petrificação, instituída pelo constituinte. Por conseguinte, Dahl acredita na existência de direitos democráticos necessários para a manutenção dos jogos políticos, daí porque a maioria não os pode revogar, sem degenerar o regime democrático para uma representação de interesses privados, então, " [...] se deduce que las acciones que debilitarían significativamente o que incluso destruirían estos derechos no pueden ser legítimas e bien se pueden colocar fuera de la autoridade legal y constitucional de las mayorías ${ }^{63} . "$

A Constituição Federal de 1988 não se tornara prolixa apenas em decorrência do temor decorrente dos anos de exceção que se dera durante o Regime Militar após 1964, ou mesmo diante das instabilidades por que passou nossa história constitucional desde a República de 1889, ou seja, com alternâncias de regimes democráticos com ditaduras, e mesmo naquelas a total ausência de efetividade dos direitos fundamentais por parte da centralização do Poder Executivo. A enumeração de vários direitos fundamentais, que são a base para a existência digna do ser humano, é um

62 DAHL, 2008, p. 29

63 DAHL, 2008, p. 29 
compromisso com o desenvolvimento do povo que lhe dá sustentação, logo "[Ela] se faz inusitadamente recamada de dispositivos para detalhar as coisas e assim revestir-se da força de governar o próprio governo e a sociedade ${ }^{64} . "$. Logo, não se olvida que a fundamentalidade material dos direitos constitucionais vincula o Poder Executivo, poder arrecadador fiscal, administrador de parcela considerável do orçamento.

Mesmo diante da existência das cláusulas de petrificação, quando ocorre uma violação dos direitos fundamentais através daquela maioria, quem poderá tornar efetiva a Constituição? Quem dentre os poderes da República levantará a voz contra o arbítrio travestido de legalidade? Há, pois, a necessidade de abertura de um canal de poder para a reclamação popular.

Apesar de não existir mais o Poder Moderador da Constituição de $1824^{65}$, hodiernamente todos os poderes são fiscais uns dos outros, pois "sem uma tal ligação que dê a cada um deles o direito constitucional de fiscalizar os outros, o grau de separação, essencial à existência de um governo livre, não pode na prática ser eficazmente mantido ${ }^{66^{\prime \prime}}$. O Judiciário, dentro de sua competência fiscalizatória, representa uma abertura de comunicação entre os poderes, não permitindo que um possa manter-se no planalto da decisão política, degenerando as atribuições constitucionais de cada função.

64 BRITTO, 2010, p.97

65 Por mais que se diga que o Judiciário seja um herdeiro do Poder Moderador, segundo Vieira (2010, p. 514 e 515) ele não é esse, pois não possui a maioria de suas prerrogativas, não podendo-se atribuir a ele mesma força.

66 HAMILTON; MADISON; JAY, 2003, p. 305 


\subsubsection{Judiciário como poder para servir e proteger os direitos fundamentais}

O Poder Judiciário, em tese, exerce uma importante função moderadora no interior do Estado Constitucional, tutelando direito e garantias das pressões majoritárias eventuais, contudo seu ativismo crescente tem fê-lo agir como sucedâneo ilegítimo do poder constituinte. O que o tem tornado objeto de duras críticas, cuja base está na sua falta de elegibilidade pelo povo ${ }^{67}$, tomando-o, por isso, como uma elite intelectual que se vê acima da vontade popular, ou seja, "[Os] juízes erguem-se acima de nós no seu isolamento das condições da vida comum ${ }^{68 "}$.

Todavia, o Poder Judiciário é criador do direito ainda que restritivamente, devendo atuar sob os limites evidentes do texto constitucional, regendo-se em sua atividade jurisdicional sob o princípio da inércia ${ }^{69}$ : "[Renovando] a lei, ambos, juiz e povo, elaboram as normas para situações emergenciais e preparam o Direito do futuro, que será tão bom quanto se compadeça com aqueles precedentes ${ }^{70^{\prime \prime}}$.

Durante algum tempo se acreditou que o enrijecimento da divisão de poderes seria condição para a existência de uma Constituição em qualquer sociedade, como se observa do art. 16 da Declaração do Homem e do Cidadão de 26 de

67 "Assim, eis a função central que é o ao mesmo tempo o problema central, do controle judicial de constitucionalidade: um órgão que não foi eleito, ou que não é dotado de nenhum grau de significativo de responsabilidade política, diz aos representantes eleitos pelo povo que eles não podem governar como desejam." (ELY, 2010, p. 08).

68 WALDRON, 2003, p. 37

69 Código de Processo Civil. “Art. 2 Nenhum juiz prestará a tutela jurisdicional senão quando a parte ou o interessado a requerer, nos casos e forma legais". (BRASIL, 2011)

70 VASCONCELOS, 2006, p. 200 
agosto $1978^{71}$, de outro, teve como fundamento a necessidade de controlar o poder para evitar seu uso abusivo ${ }^{72}$. Contudo, a separação dos poderes está hoje em plena releitura, pois, os abusos do príncipe cessaram, mas, surgem na modernidade textos legislativos que não se apoiam em preceitos proporcionais, levando o Judiciário a, não raras vezes, a afastar a aplicação dessas leis em virtude de afronta à Constituição e aos direitos e garantias fundamentais ali previstos, em um claro exemplo de cooperação entre os poderes, mas sempre com reservas aos limites definidos pela democracia constituinte. Calha à observação de Bueno quanto à necessidade de harmonia entre os poderes:

33. A par de sua independência, e distinta separação, devem os poderes concorrer pelo mesmo modo o mais harmonioso para o grande fim social. Sem o concurso uníssono de suas vistas e esforços, jamais será possível que o maquinismo político e administrativo funcione proveitosamente. A divisão dos poderes não é certamente instituída para gerar o choque, e o conflito não se distingue para que sejam rivais, ou hostis, sim para melhor garantir o destino e fim social, para que em justo equilíbrio trabalhem e cooperem, auxiliem-se, e conspirem pelo modo mais esclarecido em prol do bem-ser comum ${ }^{73}$.

71 Art. 16. A sociedade em que não esteja assegurada a garantia dos direitos nem estabelecida à separação dos poderes não tem Constituição. (VILLEY, 2007, anexo I)

72 MONTESQUIEU, 2004, p. 190. No mesmo sentido, Bueno (2002, p. 92) comenta o art. $9^{\circ}$

da Constituição de 1824. "Daí se manifesta claramente a necessidade essencial da divisão do poder. Necessidade que uma civilização adulta trata logo de satisfazer. Essa divisão é que verdadeiramente distingue e classifica as diversas formas dos governos, que extrema os que são absolutos dos que são livres, que enfim opera a distinção real dos diferentes interesses e serviços da sociedade. Sem ela o despotismo necessariamente deverá prevalecer, pois que para o poder não abusar é preciso que seja dividido e limitado, é preciso que $o$ poder contenha o poder" (sem grifo no original).

73 BUENO, 2002, p. 96 
Jorge Neto afirma que o Estado Social modificou a ótica de atuação da função jurisdicional: “[...] não cabe mais apenas estabelecer o certo e o errado com base na lei, deve antes e sobretudo, verificar se os exercícios discricionários do poder de legislar conduz à concretização dos resultados objetiva$\operatorname{dos}^{74^{\prime \prime}}$, daí porque o judiciário ganhara força com o advento do controle de constitucionalidade dos atos praticados pelo Executivo e Legislativo, esse controle é um aperfeiçoamento da democracia ${ }^{75}$.

Si el Estado de derecho es (así democraticamente entendido) império de la ley, resulta evidente que aquél es y habrá de ser por encima de todo império de la ley fundamental, império de la Constitución. Desde este punto de vista resulta obvio (casi tautológico) que todo Estado de dercho es Estado constitucional de derecho. El poder legislativo, poder prevalente - decíamos más arriba - em el ámbito del poder constituído, es y debe ser um poder, a su vez, subordinado a la Constitución: para controlar motivadamente esto existe el Tribunal Constitucional. Através de ella, aquél está y debe estar así subordinado, em última instancia, el poder constituyente - supremo poder soberano - que es quien, siguiendo los procedimentos por él estabelecidos, puede asimismo revisar y reformar la própria Constitución ${ }^{76}$..

Importa registrar que a instalação do contraditório para que se possa efetivamente convencer o magistrado reflete uma real participação na decisão, já que o magistrado deverá

74 JORGE NETO, 2008, p. 67

75 A Constituição da República Federativa do Brasil confere ao poder judiciário, em especial ao Supremo Tribunal Federal, a guarda da Constituição, art. 102, cabeça, da CF/88. No mesmo sentido, poder-se-ia falar no Superior Tribunal de Justiça como guardião da interpretação uníssona da legislação federal, art. 105, III, ' $c$ ', esse exerce aqui o balanço de olhos entre o texto legislativo federal, a Constituição e a realidade pluralística.

76 DÍAZ, 2002, p. 73. 
enfrentar todos os argumentos trazidos aos autos. Outros institutos como a publicidade dos atos processuais (art. $5^{\circ}$, LX) e a necessidade de motivação das decisões judiciais (art. 93, IX), ambos constantes na Constituição de 1988, constroem a abertura democrática do Judiciário. A publicidade do ato judicial mostra como a jurisdição é agente da democracia, uma vez que a publicidade se opõe ao arcana imperii, logo, “[...] a república democrática - res publica não apenas no sentido próprio da palavra, mas também no sentido de exposta ao público - exige que o poder seja visível ${ }^{77}$."

Não obstante, uma das prementes tensões entre Legislativo e Judiciário está na alegada intervenção desse em matérias jurídico-políticas ${ }^{78}$, na medida em que muitos acreditam que a função jurisdicional somente pode se ater às demandas individuais apresentadas, devendo deixar aos outros poderes, que possuem integrantes eleitos, o gerenciamento do Estado brasileiro. Barbosa posiciona-se nesse tema, demonstrando que como integrante da tripartição, não se pode pensar o Judiciário apartado de decisões jurídico-políticas: “Embora, porém, até certa altura política o terreno onde ele penetre, judiciárias serão as questões, que levantar, desde que viole direitos articulados na Constituição, ou use de atribuições, que esta manifestamente lhe não reconheça ${ }^{79^{\prime \prime}}$. Modernamente não se discrepa desse entendimento: "O que se pode concluir é que a judicialização da política é uma

77 BOBBIO, 2007, p. 29-30

78 Aqui se utilizará o termo jurídico-políticas para as demandas consideradas políticas, uma vez que não se pode afastar o a juridicidade da política constante da Constituição de 1988, na medida em que ações políticas têm direta ou indiretamente atender os direitos fundamentais, mesmo que se admita que a política é no Estado forma de controle, mas mesmo aquela para manter-se deve contar com legitimidade, e o povo é, ainda, balança da legitimidade.

79 BARBOSA, 1983, p. 131 
conseqüência da supremacia da constituição (que colocou os três poderes, a priori, numa mesma hierarquia e abaixo dos ditames do constituinte) e do controle da constitucionalidade ${ }^{80}$." Ora, caso não se considere o Judiciário como uma das pernas do tripé, e na medida em que uma das pernas desse é menor ou mesmo inexistente, perde-se sua função de base para sustentar o objeto, e esse, aqui, é o Estado Democrático de Direito instituído pela República Federativa do Brasil: " $[\mathrm{Em}]$ verdade, a justiça constitucional se tornou uma premissa da democracia: a democracia jurídica, a democracia com legitimidade ${ }^{81}$." A previsão constitucional no art. $2^{\circ}$ dos poderes não é mera retórica, mas sim, convicção constituinte da importância de cada um deles, "[Para] que a governabilidade legislativa e executiva seja tão-só a que verdadeiramente conta: a governabilidade constitucional ${ }^{82}$."

Cabe sublinhar que o Judiciário não está imune à vinculação pelos direitos fundamentais, pois "as constituições modernas, como contratos sociais na forma escrita e positiva, têm a finalidade de limitar e vincular os poderes que, de outro modo seriam absolutos ${ }^{83}$. . O Poder Judiciário passa a ser visto como elemento de democracia na medida em que atua como pêndulo de compatibilização dos textos legais com a Constituição, funcionalizando suas interpretações, ou seja, buscando normas jurídicas que se adequem ao pluralismo social hodierno, daí a necessidade de haver uma interpretação de todo o texto legislativo, não mais se podendo acreditar que na clareza da lei não mais se interpreta, pois se há clareza é por que essa já foi objeto de compreensão ${ }^{84}$.

80 ALBUQUERQUE, 2011, p. 90

81 BONAVIDES, 2008, p. 317

82 BRITTO, 2010, p. 107 e 113

83 CAMBI, 2010, p. 29

84 "Pelo quê se conclui que a reclamada segurança da lei só se encontra na 


\section{Conclusão}

O povo é um elemento de difícil identificação, ou seja, quem e, ou quantos são, ou mesmo como cada um participa da construção do poder? Essas indagações servem de húmus para um contínuo revisitar o povo. Isso se dá na medida em que o povo como novo absoluto do poder soberano sofreu ao longo dos anos em um conceito camaleão, uma constante mudança. Contudo, tem mantido como norte uma abertura semântica, agregando mais indivíduos em seu guarda chuva.

O alargamento da ideia de povo cresce diretamente com a relevância dos direitos fundamentais. Essa relação está nitidamente presente na democracia. Nesse sentido, observa-se que a participação popular em âmbitos de decisão, quer institucional, quer não institucional, se dá pela existência de um umbral legitimador, ou seja, abaixo de certo nível de inclusão no espaço público ocorre uma perda de legitimidade na decisão. Dessa forma, quem dá forma e estrutura para esse umbral são dos direitos fundamentais, onde se prevê várias regras e princípios de igual liberdade para o povo. Assim, as deliberações além de contar com uma maior participação, impedem que os participantes transacionem suas vontades por favores ligados ao acesso à saúde, a alimentação, educação e etc. Os direitos fundamentais são precondições para uma democracia integrada e participativa, que cobra "responsividade" das funções públicas do Legislativo, Executivo e Judiciário, portanto, se chegou ao ponto, de ter se tornado praticamente impossível, pensar um sem o outro.

norma jurisprudencial, que é a sua interpretação. Dessa nunca se há de prescindir, porque, por mais clara que se afigure a lei, ela sempre dispõe de modo geral, competindo ao intérprete particularizá-la segundo os dados e as circunstâncias do caso concreto. Como já se notou, a própria afirmação de sua clareza pressupõe interpretação. E mais: interpreta-se até o seu silêncio e sua ausência." (VASCONCELOS, 2006, p. 199) 
Assim, o Poder Legislativo é o ambiente institucional por excelência da deliberação política, logo a participação direta do povo deve ser estimulada como elemento legitimador da decisão política. Ademais, a representação não pode ser observada apenas sob uma ótica realista, mas dentro da perspectiva normativa demonstrar como se pode melhorar o ambiente comunicacional a fim de favorecer as precondições democráticas, os direitos fundamentais. Na defesa das precondições de participação o Poder Judiciário atua como um instrumento de cobrança e fiscalização do Legislativo, para que esse não escamoteia as normas constitucionais. Não obstante, nesse cenário o Judiciário não pode se constituir como um poder elitista, daí a existência de instrumentos que permitem seu controle, tanto intra-juridicional, e.g, recursos e fundamentação, como extra-juridicional, como a publicidade.

A ligação umbilical entre democracia e direitos fundamentais, notadamente, nos países capitalistas periféricos, carecedores da generalização até dos direitos civis, quanto mais dos direitos sociais e políticos é mais problemática. Dado que uma democracia não pode significar só apego a ritos de votação inócuos, de maiorias ou minorias abstratas, posto que cingidas aos limites de uma ordem proprietarista para poucos oligarcas. Como manter um umbral de legitimação do pode?

Unicamente um Estado Democrático de Direito como síntese de múltiplas determinações, terá êxito na operosa tarefa de combinar um processo dialético entre política e normatividade, fugindo das tendências redutoras do unilateralismo. Um Estado Democrático de Direito que seja a premissa para o desenvolvimento futuro de uma nova radicalidade política capaz de encetar a densificação dos valores da igualdade, da liberdade e da participação, superando as formas 
heterônomas com que o poder moderno e contemporâneo ainda se reveste. Mas, antes de tudo, uma democracia que seja compreendida com base na dimensão ativa, subjetiva e instituinte do povo, ao contrário dos paradigmas alienantes da política e do direito produzidos pela modernidade liberal-burguesa esvanecida, que transforma a democracia em apanágio do mercado em que os homens são atomizados para, depois, serem agregados abstratamente de acordo com uma sociedade irreal, produto da desfiguração do sentido imanente da política e da criação jurígena do direito.

Nota-se hodiernamente uma crise de sentido da política, do direito, da democracia, mais exatamente de suas figurações liberais, impossibilitadas estas de apreenderem o metabolismo autêntico, existencial dos homens comuns, desejosos do comum, do livre fluxo das intersubjetividades. Retomar o fio do sujeito, sublinhando o papel da voz da autonomia nos processos comunicacionais entre os indivíduos e grupos, parece crucial, sem o que não existe nem direito, nem democracia, nem direitos fundamentais.

A luta pela Constituição de 88 , nesse exato momento histórico, é a luta pelo resgate de um processo aberto de incorporação dos plúrimos sujeitos da vida brasileira, fundado no reconhecimento e dignidade que lhes é inerente, em que o ordenamento maior seja menos um ponto inelutável de chegada, mas sim de partida para o desencadeamento de novos processos de conquistas de novos direitos e possibilidades.

\section{Referencias bibliográficas}

ALBUQUERQUE, Felipe Braga. Direito e política: pressupostos para a análise de questões políticas pelo judiciário à luz do princípio democrático. Tese (Doutorado em Direito)- Universidade de Fortaleza. Fortaleza, 2011. Dispo- 
nível em: <http:/ / uol-ebt-86.unifor.br/oul/conteudosite/ F8602712411/Tese.pdf>. Acesso em: 24 jul. 2012.

BARBOSA, Rui. Obras completas: o direito do amazonas ao acre setentrional. 1910. Rio de Janeiro: Ministério da Educação e Cultura: Fundação Casa de Rui Barbosa. 1983. v. XXXVII. t.V.

BITTAR, Eduardo C. Doutrinas e filosofias políticas: contribuição para a história da ciência política. São Paulo: Atlas, 2002.

BOBBIO, Norberto. Estado, governo, sociedade: para uma teoria geral da política. 13. ed. São Paulo: Paz e Terra, 2007.

BRITTO, Carlos Ayres. O humanismo como categoria constitucional. Belo Horizonte: Fórum, 2010.

BUENO, José Antônio Pimenta (Marquês de São Vicente). Direito público brasileiro e análise da constituição do Império. Organização e introdução por Eduardo Kugelmas. São Paulo: Ed. 34, 2002. (Coleção Formadores do Brasil).

CAMBI, Eduardo. Neoconstitucionalismo e neoprocessualismo: direitos fundamentais, políticas públicas e protagonismo judiciário. São Paulo: Revista dos Tribunais, 2009.

CARVALHO, José Murilo de. Cidadania no Brasil: o longo caminho. 14. ed. Rio de Janeiro: Civilização Brasileira, 2011.

CYRINO, André. Como se fazem as leis? Democracia, Grupos de Interesse e Controle de Constitucionalidade. In: Revista Brasileira de Estudos Políticos, $n^{0} 113$, pp 51-99, jul./ dez. 2016.

DAHL, Robert A. La igualdad política. Traducido por: Liliana Andrade Llanas. Buenos Aires: Fondo de Cultura Económica, 2008.

DÍAZ, Elías. Estado de derecho y legitimidad democrática. In: CARBONELL, Miguel; OROZCO, Wistano; VÁZQUEZ, 
Rodolfo (Coord.). Estado de derecho: concepto, fundamentos y democraización em América Latina. México: Silgo XXI editores, em coedición com el instituto de insvestigaciones jurídicas de la UNAM y el Instituto Tecnológico Autónomo de México, 2002. p. 61-93.

ELY, Jonh Hart. Democracia e desconfiança: uma teoria do controle judicial de constitucionalidade. Tradução Juliana Lemos. São Paulo: Editora WMF Martins Fontes, 2010.

FERRAJOLI, Luigi. Derechos y garantias: la ley del más débil. 7. ed. Madrid: Trotta, 2010.

. Por uma teoria dos direitos e dos bens fundamentais. Tradução: Alexandre Salim, Alfredo Copetti Neto, Daniela Cadmartori, Hermes Zaneti Junior e Sérgio Cademartori. Porto Alegre: Livraria do Advogado, 2011.

. Garantismo. Uma discussão sobre direito e democracia. Prefácio e tradução Alexandre Araujo de Souza. Rio de Janeiro: Lumen Juris, 2012.

FURTADO, Luísa Elisabeth Timbó C. O Estado democrático de direito e sua relação com os direitos fundamentais. Pensar - Revista do Curso de Direito da Universidade de Fortaleza, Fortaleza, v. 2, p. 112-130, 1993.

GOYARD-FABRE, Simone. Os princípios filosóficos do direito político moderno. Tradução: Irene A. Paternot. São Paulo: Martins Fontes, 2002.

HABERMAS, Jünger. Direito e democracia: entre facticidade e validade. $2^{\mathrm{a}}$ ed. Tradução Flávio Siebneichler. Rio de janeiro: Tempo Brasileiro, 2012, vol. 1.

HAMILTON, Alexander; MADISON, James; JAY, Jonh.

O Federalista. Tradução Hiltomar Martins Oliveira. Belo Horizonte: Ed. Líder, 2003. 
HELLER, Hermann. Teoria do Estado. Tradução Lycurgo Gomes da Motta, supervisão João Mendes de Almeida. São Paulo: Mestre Jou, 1968.

JORGE NETO, Nagibe de Melo. O controle jurisdicional das políticas públicas: concretizando os direitos sociais fundamentais. Salvador: Jus Podivm, 2008.

LINARES, Sebastían. Democracia Participativa Epistémica. Madrid: Marcial Pons, 2017.

LOPES, José Reinaldo Lima. O Supremo Tribunal de Justiça no apogeu do Império (1840-1871). In: LOPES, José Reinaldo de Lima (Org.). O Supremo Tribunal de Justiça do Império: 1828 - 1889. São Paulo: Saraiva, 2010. p. 63-103. (Coleção direito, desenvolvimento e justiça. Série Produção Científica).

LOSURDO, Domenico. Democracia ou bonapartismo: triunfo e decadência do sufrágio universal. Tradução: Luiz Sérgio Henriques. Rio de Janeiro: UFRJ; UNESP, 2004.

MARTÍ, José Luis. La República deliberativa. Una teoria de la democracia. Madrid: Marcial Pons, 2006.

MARX, Karl; ENGELS, Friedrich. Manifesto do Partido Comunista. Tradução: Marcos Aurélio Nogueira e Leandro Konder. Petrópolis: Vozes, 2011.

MONTESQUIEU, Charles-Louis de Secondat. Do espirito das leis. Tradução, introdução e notas de Edson Bini. Bauru: EDIPRO, 2004.

MÜLLER, Friedrich. Quem é o povo? A questão fundamental da democracia. Tradução: Peter Neumann, rev. trad. Paulo Bonavides. 6. ed. rev. atual. São Paulo: Revista dos Tribunais, 2011.

ROUSSEAU, Jean-Jacques. Do contrato social ou princípios do direito político. Tradução: Eduardo Brandão. São Paulo: Penguin Classics Companhia das Letras, 2011. 
SARTORI, Giovanni. A teoria da democracia revisitada - o debate contemporâneo. Tradução: Dinah de Abreu Azevedo. São Paulo: Ática, 1994. v. I. (Série Fundamentos, 104).

SOUZA NETO, Cláudio Pereira. Teoria Constitucional e Democracia Deliberativa: um estudo sobre o papel do direito na garantia das condições para a cooperação na deliberação democrática. Rio de Janeiro: renovar, 2006.

TEXEIRA, Anderson VichinKeski; RADKE, Rafael Wagner. Habermas e a tentativa procedimental de superação da discricionariedade. In: Revista Brasileira de Estudos Políticos, no 115, pp 81 -108, jul./dez. 2017.

TEXIER, Jacques. Revolução e democracia em Marx e Engels. Tradução: Duarte Pacheco Pereira. Rio de Janeiro: UFRJ, 2005.

VASCONCELOS, Arnaldo. Teoria da norma jurídica. 6. ed. São Paulo: Malheiros, 2006.

WALDRON, Jeremy. A dignidade da legislação. Tradução: Luís Carlos Rodrigues. Rev. Trad. Marina Appenzeller. São Paulo: Martins Fontes, 2003.

Recebido em 26/05/2018.

Aprovado em 02/10/2018.

\section{Augusto Eduardo Almendra Martins}

E-mail: eduardoalmendra@yahoo.com.br

Newton de Menezes Albuquerque

E-mail: newtonma@uol.com.br 
